\title{
Entrepreneurship Education in Higher Education as an Alternative to Reduce Educated Unemployed in Indonesia
}

\author{
Universitas Sebelas Maret \\ meylikhusna14@gmail.com
}

Meyli Khusna Yuliana, Mararti, Nur Ulil Absoriah

\section{Article History}

accepted 24/09/2019

\begin{abstract}
This article aims as an effort that can be done to overcome the increasing educated unemployment by preparing college graduates who are not only oriented to job seekers but also as job creation. The research method used is literature study, data collection is carried out using a study of books, literature, notes, reports, and the internet which has to do with the problem being solved. The sources of literature in this study were obtained from books, journals, and research results (thesis, thesis, dissertation) so that this article covers general processes such as systematically identifying theories, library discoveries and analytical documents related to research topics. The expected outcome is in the form of learning methods about entrepreneurship that can be developed in higher education as an alternative to entrepreneurship development for students.
\end{abstract}

Keywords: Educated unemployment, entreupeneurship, employment

\begin{abstract}
Abstrak
Artikel ini bertujuan sebagai upaya yang dapat dilakukan untuk mengatasi pengangguran terdidik yang terus meningkat dengan menyiapakan lulusan perguruan tinggi yang tidak hanya berorientasi pada pencari kerja tetapi juga sebagai pencipta lapangan pekerjaan. Metode penelitian yang digunakan yakni dengan studi kepustakaan, pengumpulan data dilakukan dengan menggunakan studi penelaahan terhadap buku-buku, literatur-literatur, catatan-catatan, laporan-laporan, dan internet yang ada hubungannya dengan masalah yang dipecahkan. Sumber-sumber kepustakaan dalam penelitian ini diperoleh dari buku, jurnal, dan hasil penelitian ( skripsi, tesis, disertasi ) sehingga dalam artikel ini meliputi proses umum seperti mengidentifikasikan teori secara sistematis, penemuan pustaka dan analitis dokumen yang berkaitan dengan topik penelitian. Hasil yang diharapkan berupa cara-cara pembelajaran tentang kewirausahaan yang dapat dikembangkan di perguruan tinggi sebagai alternatif pengembangan kewirausahaan bagi mahasiswa.
\end{abstract}

Kata kunci: Pengangguran terdidik, kewirausahaan, lapangan pekerjaan.

Social, Humanities, and Education Studies (SHEs): Conference Series https://jurnal.uns.ac.id/shes

p-ISSN 2620-9284 e-ISSN 2620-9292 


\section{PENDAHULUAN}

Permasalahan baru adalah dalam kurun waktu 10 tahun terakhir lulusan perguruan tinggi indonesia yang menjadi pengangguran semakin meningkat. Dibuktikan dalam data BPS (Badan Pusat Statistik) yang diunggah pada tanggal 23 Januari 2019 melalui situs https://www.bps.go.id/ menayangkan tabel dalam kategori lulusan sekolah, antara lain tidak/belum pernah sekolah, tidak/belum tamat SD, SD, SLTP, SLTA Umum, SLTA Kejuruan, Akademi/Diploma, dan Universitas. Seseorang yang telah lulus pendidikan dan ingin mendapatkan pekerjaan tetapi belum dapat memperolehnya disebut dengan pengangguran terdidik. Para penganggur terdidik biasanya dari kelompok masyarakat menengah ke atas yang memungkinkan adanya jaminan kelangsungan hidup meski menganggur. Tingkat pengangguran terdidik di Indonesia masih tinggi, khususnya pengangguran terdidik yang berasal dari univeritas baik itu sarjana maupun diploma, menurut Elwin Tobing (2000) meningkatnya pengangguran terdidik merupakan gabungan beberapa penyebab, salah satunya adalah semakin terdidik seseorang, semakin besar harapannya pada jenis pekerjaan yang aman. Golongan ini menilai tinggi pekerjaan yang stabil dari pada pekerjaan yang beresiko tinggi sehingga lebih suka bekerja pada perusahaan besar dari pada membuka usaha sendiri. Hal ini diperkuat hasil study Clignet (1980) yang menemukan gejala meningkatnya pengangguran terdidik di Indonesia antara lain disebabkan adanya keinginan memilih pekerjaan yang aman dan jauh dari resiko. Dengan demikian angkatan kerja terdidik lebih suka memilih menganggur dari pada memperoleh pekerjaan yang tidak sesuai dengan keinginan mereka.

Dari pemaparan di atas yang dikemukakan oleh (Elwin Tobing, 2000), dapat kita simpulkan bahwa kebanyakan lulusan dari perguruan tinggi bermental pegawai baik itu pegawai swasta yang bekerja disebuah perusahaan maupun sebagai aparatur sipil negara (ASN) yang bekerja di Instansi milik pemerintah. Kebanyakan lulusan perguruan tinggi lebih suka bekerja disektor formal daripada membuka usaha atau bisnis dan membuka lapangan pekerjaan. Hal ini karena minat dan motivasi pemuda Indonesia khususnya mahasiswa untuk berwirausaha masih rendah. Fenomena rendahnya minat dan motivasi pemuda Indonesia khususnya mahasiswa dalam berwirausaha menjadi pemikiran serius berbagai pihak baik pemerintah, dunia pendidikan, dunia industri, maupun masyarakat luas.

Wiraswasta yang berasal dari kata Wira berarti berani, utama, teladan, Swa berarti sendiri, Sta berarti berdiri. Sehingga wiraswasta diartikan orang yang berani berdiri sendiri. Istilah lain yang sering dipakai sebagai padanan dari wiraswasta adalah wirausaha. Menurut INPRES No 4 Th. 1995 kewirausahaan adalah semangat, perilaku dan kemampuan seseorang dalam menangani usaha dan atau kegiatan yang mengarah pada upaya mencari, menciptakan, menerapkan cara kerja, tehnologi dan produk baru dengan meningkatkan efisiensi dalam rangka memberikan pelayanan yang lebih baik dan atau memperoleh keuntungan yang lebih besar (Susilaningsih, 2015). Sedangkan asas pokok kewairausahaan adalah : (1) Kemampuan yang kuat untuk berkarya dengan semangat kemandirian; (2) Kemampuan memecahkan masalah dan mengambil keputusan secara sistematis termasuk keberanian mengambil resiko usaha; (3) Kemampuan berpikir dan bertindak secara kreatif dan inovatif; (4) Kemampuan bekerja secara teliti, tekun dan produktif; (5) Kemampuan dan kemauan untuk berkarya dalam kebersamaan berlandaskan etika bisnis yang sehat.

Bentuk pendidikan yang diberikan berupa pentaran-penataran mengenai kewirausahaan. Untuk menjamin kelancaran pelaksanaan, Lembaga Bina Wiraswasta telah menyusun program pendidikan yang terdiri atas : (1) Program Aji Tunas Wiraswasta bagi drop-outs pengusaha kecil, pramuka, pengurus koperasi mahasiswa dan karyawan; (2) Program Aji Karya Wiraswasta bagi pra pengusaha, manajer perusahaan, sarjana dan pejabat; (3) Program Tata Keluarga Wiraswasta bagi orang tua dan kaum wanita. Rumusan masalah dalam penelitian ini adalah bagaimana upaya 
yang dapat dilakukan untuk menumbuhkan jiwa kewirausahaan di kalangan pemuda khususnya mahasiswa di perguruan tinggi terutama untuk mengubah mindset pemuda Indonesia khususnya mahasiswa yang hanya berminat menjadi pegawai swasta, ASN ( Aparatur Sipil Negara) dan sebagai pencari kerja (job-seeker).

\section{METODE}

Metode yang digunakan adalah studi kepustakaan, menurut Nazir (2003) mengemukakan bahwa "Studi kepustakaan adalah teknik pengumpulan data dengan mengadakan studi penelaahan terhadap buku-buku, literatur-literatur, catatan-catatan, dan laporan-laporan yang ada hubungannya dengan masalah yang dipecahkan". Peneliti melakukan kajian yang berkaitan dengan teori yang terkait dengan topik penelitian, mengumpulkan informasi sebanyak-banyaknya dari kepustakaan yang berhubungan dengan cara-cara mengurangi pengangguran terdidik melalui pendidikan kewirausahaan yang diterapkan sebagai metode pembelajaran dan pengembangan wirausaha bagi mahasiswa di perguruan tinggi.

\section{HASIL DAN PEMBAHASAN}

Pemberian pengetahuan tentang kewirausahaan bagi kelompok strategis dalam masyarakat, salah satunya adalah dunia kampus yang dapat mempercepat pembangunan karakter masyarakat yang lebih berorientasi kepada produktivitas, karena penanaman sikap kewirausahaan melalui gerakan moral yang didukung oleh sikap ilmiah yang akan lebih mempertebal rasa percaya diri, inisiatif dan kreatifitas. Cara-cara yang dapat dikembangkan di perguruan tinggi untuk menumbuhkan dan membekali mahasiswanya dengan ilmu berwirausaha, antara lain (Pengelolaan Program Hibah DP2M Ditjen Dikti - Edisi VII):

\section{Kuliah Kewirausahaan (KKU)}

Tujuan KWU adalah meningkatkan pemahaman dan penjiwaan kewirausahaan dikalangan mahasiswa agar menjadi wirausahawan yang berwawasan jauh ke depan dan luas berbasis ilmu yang diperolehnya, dapat mengenal pola pikir wirausaha serta meningkatkan pemahaman manajemen dan memperkenalkan cara melakukan akses informasi dan pasar serta teknologi. Selama menjadi pilot project, Kuliah Kewirausahaan yang setara dengan 2 sks, menjadi tanggung jawab LPM perguruan tinggi pengusul, sedangkan Jurusan/Fakultas sebagai pelaksana, di bawah koordinasi Pembantu/Wakil Rektor urusan akademis.

Kegiatan KWU dilaksanakan dalam lingkup dan tahapan: (1) Persiapan kuliah yang mencakup seleksi calon peserta, penyusunan kurikulum, silabus, satuan acara perkuliahan, modul dan simulasi kewirausahaan, penentuan tolok ukur keberhasilan, penetapan pengajar baik dari perguruan tinggi maupun praktisi/pengusaha; (2) Pelaksanaan kuliah melalui tatap muka, simulasi, penugasan penyusunan rencana bisnis yang operasional dan diperkaya dengan kunjungan ke industri; (3) Evaluasi terhadap proses belajar Panduan Pengelolaan Program Hibah DP2M Ditjen Dikti Edisi VII 225 mengajar, evaluasi diri dan evaluasi terhadap pelaksanaan kegiatan; (4) Penyusunan business plan oleh mahasiswa peserta KWU; (5) Pemantapan pelaksanaan yang dilakukan melalui pengembangan dan penyempurnaan materi, perbaikan kualitas pengajar serta pelaksanaan kuliah untuk tahun akademik berikutnya.

\section{Magang Kewirausahaan (MKU)}

Magang Kewirausahaan dilaksanakan untuk memberikan pengalaman praktis kewirausahaan kepada mahasiswa dengan cara ikut bekerja sehari-hari pada usaha kecil dan menengah. Tujuan MKU adalah: (1) Meningkatkan kemampuan untuk menerapkan pengetahuan dan ketrampilan yang dimiliki; (2) Meningkatkan pengetahuan kewirausahaan mahasiswa baik dalam hal keilmuan maupun pengalaman berwirausaha; (3) Meningkatkan kemampuan berkomunikasi dan 
bersosialisasi dengan kalangan masyarakat di perusahaan; (4) Memacu motivasi kewirausahaan mahasiswa yang berminat menjadi calon wirausaha; (5) Membuka peluang untuk memperoleh pengalaman praktis kewirausahaan bagi dosen pembimbing mahasiswa; (6) Menciptakan keterkaitan dan kesepadanan antara perguruan tinggi dengan UMKM.

Magang Kewirausahaan dilaksanakan oleh Jurusan/Fakultas di bawah koordinasi LPM perguruan tinggi pengusul. Kegiatan MKU dilaksanakan dalam lingkup: (1) Penetapan usaha kecil menengah yang layak untuk tempat magang; (2) Pembekalan magang mahasiswa oleh dosen pembimbing; (3) Temu gagasan antara perguruan tinggi dengan pimpinan perusahaan mitra; (4) Pelaksanaan MKU; (5) Pemantauan dan pembimbingan oleh dosen pembimbing dan perusahaan tempat magang; (6) Evaluasi pelaksanaan magang oleh mahasiswa, pengusaha dan dosen pembimbing; (7) Penyusunan business paln oleh mahasiswa peserta magang; (8) Penulisan laporan magang oleh mahasiswa; (9) Pembahasan hasil magang yang diikuti semua pihak yang terkait.

\section{Kuliah Kerja Usaha (KKU)}

Tujuan khusus yang ingin dicapai dari KKU adalah: (1) Berkembangnya budaya kewirausahaan di perguruan tinggi; (2) Terwujudnya calon sarjana yang cendekiawan dan berjiwa kewirausahaan serta sadar dengan masalah lingkungannya; (3) Menumbuh kembangkan usaha kecil menengah yang memiliki daya saing tinggi dari segi kualitas produk/jasa, kinerja dan pemasaran.

Kuliah Kerja Usaha dilaksanakan oleh suatu Tim Dosen dibentuk LPM dalam suatu wilayah dengan lingkup dan tahapan: (1) Pembekalan Panduan Pengelolaan Program Hibah DP2M Ditjen Dikti - Edisi VII 254 bagi mahasiswa KKU dalam rangka membangkitkan potensi wirausaha, menyamakan persepsi sifat dan karakteristik UKM serta cara untuk meningkatkan usahanya, meningkatkan kesiapan mahasiswa untuk pendekatan sosial, dinamika kelompok, teknologi tepat guna dan tepat usaha; (2) Pemutakhiran data awal melalui identifikasi lokasi, masyarakat dan potensinya; (3) Pelaksanaan KKU di UKM Mitra; (4) Pemantauan dan pembimbingan oleh dosen pembimbing secara berkala; (5) Evaluasi pelaksanaan KKU oleh tim pelaksana terutama untuk mengetahui potensi ekonomi produk, nilai tambah produk dari sisi Ipteks, manfaat bagi mitra usaha, bagi peserta KKU, tim pelaksana/pembimbing dan nilai tambah bagi institusi pelaksana; (6) Penyusunan business plan oleh mahasiswa peserta KKU.

\section{Konsultasi Bisnis dan Penempatan Kerja (KBPK)}

Tujuan KBPK adalah membantu pengusaha kecil dan menengah serta alumni perguruan tinggi untuk meningkatkan usahanya dengan cara: (1) Memberikan konsultasi manajemen, pemasaran, dan teknologi berdasarkan hasil penelitian yang sudah ada; (2) Membantu lulusan perguruan tinggi mendapatkan lowongan kerja.

Kegiatan KBPK dilaksanakan oleh unit khusus di bawah naungan LPM dengan lingkup pekerjaan (Panduan Pengelolaan Program Hibah DP2M Ditjen Dikti - Edisi VII,): (1) Identifikasi program konsultasi yang sesuai dengan kebutuhan pasar masyarakat lokal maupun potensi perguruan tinggi; (2) Kompilasi basis data sumberdaya pendukung kewirausahaan; (3) promosi KBPK pada UKM; (4) Pelaksanaan konsultasi bisnis dan teknologi pada UKM masyarakat umum dan alumni; (5) Membantu wirausahawan dalam penyusunan rencana bisnis; (6) Memprakarsai temu usaha dengan melibatkan lembaga pemasaran, sumber daya keuangan, lembaga pelatihan, dan sumberdaya informasi; (7) Tindak lanjut realisasi permintaan kredit dan kemitraan usaha dengan pihak terkait; (8) Evaluasi keberhasilan; (9) Memprakarsai pencari kerja Panduan Pengelolaan Program Hibah DP2M Ditjen Dikti - Edisi VII 270 dengan perusahaan yang membutuhkannya berdasarkan data perusahaan dan pencari kerja yang dipunyai; (10) Memberikan konsultasi tentang lowongan pekerjaan. 
Kegiatan KBPK dapat diajukan maksimum 3 tahun berurutan dalam upaya mengembangkan kelembagaan KBPK. Rencana kegiatan tahun pertama harus rinci, tahun kedua dan ketiga boleh secara garis besar, setiap tahun harus dirinci dan dituangkan dalam laporan tahunan.

\section{Inkubator Wirausaha baru (INWUB)}

Inkubator Wirausaha Baru (INWUB) adalah suatu fasilitas fisik yang dikelola sejumlah staf dan menawarkan suatu paket terpadu kepada alumni perguruan tinggi yang berminat menjadi wirausahawan.

Tujuan dibentuknya INWUB adalah: (1) Menciptakan UKM yang mandiri dan berlandaskan Ipteks untuk memperkuat struktur ekonomi nasional; (2) Menciptakan lapangan kerja baru sehingga meningkatkan standar hidup golongan ekonomi lemah; (3) Membantu alih teknologi dari teknologi konvensional ke teknologi mutakhir (state of the art technology) yang tepat guna termasuk teknologi hasil putaran (spin off) industri besar, perguruan tinggi atau lembaga penelitian; (4) Mempercepat perkembangan kewirausahaan di Indonesia untuk mencapai pengembangan ketahanan ekonomi yang berkelanjutan.

INWUB di Indonesia mengembangkan 2 macam program, yaitu program bagi tenant yang membutuhkan sarana fisik ruang usaha (inwall tenant), dan tidak membutuhkan sarana fisik (outwall tenant). Kegiatan INWUB dapat diajukan untuk dilaksanakan dalam 3 tahun berurutan dengan pembiayaan dari Dikti dan perguruan tinggi. Tahun pertama harus disusun secara rinci, tahun kedua dan ketiga boleh secara garis besar dan setiap akhir tahun kegiatan harus dirinci dan dituangkan dalam Laporan Pelaksanaan tahun kegiatan, untuk dinilai kelayakan kelanjutan kegiatan.

\section{SIMPULAN}

Ketimpangan antara pencari kerja terdidik dengan lapangan kerja yang tersedia menyebabkan banyak pengangguran, hal ini diperparah dengan banyaknya perguruan tinggi yang setiap tahun mengeluarkan lulusan-lulusan baru yang menjadikan semakin besarnya angka pengangguran terdidik. Oleh karena itu, dibutuhkan sebuah cara untuk mengurangi pengangguran terdidik. Salah satunya, dengan pendidikan kewirausahaan di perguruan tinggi.

Pendidikan kewirausahaan di perguruan tinggi berkaitan dengan membangun karakter wirausaha, pola pikir wirausaha, dan perilaku wirausaha yang selalu kreatif dan inovatif, menciptakan nilai tambah atau nilai-nilai baik (values), memanfaatkan peluang dan berani mengambil resiko. Menghadapi tantangan masa depan yang sangat kompetitif, maka perilaku kewirausahaan diperlukan bagi semua bidang atau profesi. Pekerjaan oleh karena itu pendidikan kewirausahaan dapat dilaksanakan di perguruan tinggi dan diberlakukan kepada semua mahasiswa tanpa memandang bidang ilmu yang dipelajari, karena pendidikan kewirausahaan bukan pendidikan bisnis (Susilaningsih, 2015).

\section{DAFTAR PUSTAKA}

pgsd.uad.ac.id. (2019) Panduan Pengelolaan Program Hibah DP2M Ditjen Dikti - Edisi VII diakses tanggal 27 September 2019 pukul 09.20 dari https://pgsd.uad.ac.id/wp-content/uploads/Bukull2006Kewirausahaan.pdf

Susilaningsih. (2015). Pendidikan Kewirausahaan di Perguruan Tinggi : Pentingkah Untuk Semua Profesi ?. Diakses tanggal 18 September 2019 pukul 12.00 dari https://journal.uny.ac.id/index.php/economia/article/viewFile/7748/6665

www.bps.go.id. (2019) Keadaan Ketenagakerjaan Indonesia Februari 2019. Diakses tanggal $24 \quad$ September 2019 pukul 20.36 dari https://www.bps.go.id/pressrelease/download.html?nrbvfeve=MTU2NA\%3D\%3 D\&sdfs=ldjfdifsdjkfahi\&twoadfnoarfeauf=MjAxOS0wOS0yNCAyMDoyMzowOQ $\% 3 \mathrm{D} \% 3 \mathrm{D}$ 